library science, and many others. Other enthusiasms of his, such as that for the development of an adequate theory as the foundation of all professional practice, though no doubt apposite in their original context have not always been so happy when applied by others. But perhaps the most lasting impression from this volume is the forbidding character of Shera's writing: his fondness for long words and involved sentences makes him difficult to follow.

Mr. Burkett is also a teacher of librarianship, but in a very different tradition. His book when it first appeared in 1961 was something of a puzzle, because it did not seem to fit into any known category. What it does is to give an account of the various types of special libraries that exist, and describe in some detail representative specimens. Mr. Burkett has had the collaboration of many of the librarians of the libraries described, and, in this new edition, of his former colleague at the North-Western Polytechnic, Mrs. P. L. Ward. The new edition contains nearly twice as much material as the old. Mr. Burkett has also added a chapter on developments in training and resoarch in librarianship. This book has already proved itself as a mine of information for students of librarianship, and also for librarians as a reference book. It deserves to be better known by users of libraries as well.

$\mathrm{J}_{\mathrm{ACK}}$ BIRD

\section{ENERGY IN BRITAIN}

\section{Coal and the Power Industries in Postwar Britain}

By E. S. Simpson. (Longmans Geography Paperbacks.) Pp. xix +170 . (London: Longmans, Green and Co., Ltd., 1966.) 17s. 6d. net.

In his book Prof. Simpson has made good use of the reports of the nationalized fuel and power industries, the statistical digests of the Ministry of Power, statistics issued by the oil industry, and other relevant documents. From the information so obtained he has given a balanced account of the changes since 1945 in the relationship between supply and demand of the several forms of energy available in Britain. He considers particularly the changes during the period 1950 to 1962 .

The book is divided into four main parts. In the first is a review of the plans for the development of the coal industry that were based on forecasts in 1950 and 1952 of the probable demands for coal over the years to 1965 . There had been a period of shortage of fuel and demand for energy was increasing. In the circumstances it was not surprising that the plans aimed at an annual production of coal by 1960 of about 240 million tons as compared with 217 million tons in 1950 . As the author points out, these forecasts of demand proved to be too high. Though the demand for energy increased, the coal industry had to meet growing competition from oil. Total energy consumption in the country rose from the equivalent of 224 million tons of coal in 1950 to 273 million tons in 1962 , but the proportion met by coal fell from 90 to 70 per cent.

In the second part there are chapters reviewing the position over the periods 1950 to 1953 when coal was in short supply for home and export demands, 1954 to 1956 when indigenous supplies were augmented by imports of coal, and 1957 to 1962 when the demand for coal decreased and there was an accumulation of large stocks.

There are four chapters in the third part on demands for coal by direct users such as domestic consumers, certain industries, and the railways, and for the production of electricity and gas, and including a chapter on oil as the major competitor of coal. In the fourth part, on the changing pattern of energy availability, there are chapters on the mining of coal, oil refining, and on the production and distribution of electricity and gas.

The few defects in the book seem to have arisen from a lack of appreciation of certain technical considerations.
On page 69 it is said that, in the domestic market. yas. had lost the equivalent of 1.4 million tons of eoal per annum. This statement is based on the figures of the coal equivalents of the domestic consumption of gas of $9 \cdot 9$ million tons in 1952 and 8.5 million tons in 1962 given in the statistical digests of the Ministry of Power. Standing alone, this statement may be misleading, because it does not take account of the fact that the decrease in coal equivalent was due to a change in the factor of coal equivalent used in the Ministry's calculations from about 138 therms of gas equivalent to one ton of coal in 1952 to about 165 therms in 1962. In fact, as shown in another part of the hook, the domestic consumption of gas in therms was about the same throughout the period. Since 1962, after the period covered by the book, the domestic consumption of gas has risen appreciably. With the recent discovery of large reserves of gas under the North Sea and in Yorkshire there will be considerable changes in the near future in the relative demands for the different forms of energy.

In Table 29, on page 73, the figures for electricity consumption are in thousand million $\mathrm{kWh}$ and not millions as stated. In the footnote on page 91 , the figure given for the calorific value of coal on a dry ash-free basis should be per pound and not per ton. On page 98 , the calorific value of methane is given as 500 B.Th.U. per cubic foot; it should be about 1,000 B.Th.U.

It would have been interesting if the author had included a comparison of the changes in productivity in the coal industry, as given in official documents, with the changes in the costs of production. The published figures for productivity quoted in the book refer to output per manshift at the coal face and for all underground workers. On this basis the output per man-shift for underground workers rose? by 26 per cent from 1950 to 1962 , but the corresponding output per man-year rose by only 13 per cent. Over the same period, the overall wages cost per ton of coal produced increased by 55 per cent, but other costs increased by 160 per cent, so that the overall production cost increased by 92 per cont, that is, by a much greater proportion than equivalent to the rise in overall national prices due to inflation.

The book is well written and is a useful review of energy problems in Britain between 1950 and 1962. It is good value.

A. P.ARKTeR

\section{STATISTICS FOR DOCTORS}

\section{Principles of Medical Statistics}

By Austin Bradford Hill. Eighth edition. revised and onlarged. Pp. ix +381. (London: 'The Lancet, Ltd.. 1966.) 15s. net.

IN thirty years, appreciation of the vital contribution that statistical science can and should make to medical investigations has become general. No one has done more for this advance than Sir Austin Bradford Hill, and this book has been perhaps the single most potent influence.

The new edition expands the discussion of clinical trials, especially in respect of ethical questions; important statements by the Medical Research Council and the World Medical Assembly are added as an appendix. The author has also incorporated ideas on association and causation which he has recently presented elsewhere, and which emphasize more strongly than before that experimentation in medicine is not merely permissible but desirable, ethically and scientifically. They also bring out clearly the role of randomization in the design of a study, and the far greater difficulties of interpretation which arise if planned experimentation is impossible or if randomization is neglected.

Every medical student should read this book, and every clinical research worker should refer to it often.

D. J. FINNEY 